\title{
Opinions on Teaching Reform of Non-computer Majors in Higher Vocational Colleges
}

\author{
Liang Qian \\ Jingzhou Institute of Technology, Jingzhou, Hubei, 434020, China
}

Keywords: higher vocational colleges; non-computer majors; teaching reform

\begin{abstract}
In recent years, the great development of science and technology in China has driven the rapid popularization of the computer technology, so the computer course has become a required course for the non-computer majors in higher vocational collages. The integrative level of the computer teaching in China's higher vocational collages can be improved by promoting the computer application ability of vocational college students in non-computer majors. For this purpose, the teaching reform of non-computer majors in higher vocational colleges shall be implemented to make the original boring computer teaching lessons become more vivid and interesting, increase the attraction of the computer teaching practically, mobilize the subjective initiative of vocational college students to learn the computer, and make more vocational college students fall in love with the computer science. In this paper, the obvious problems in the computer teaching of non-computer majors in higher vocational colleges are expounded, and the countermeasure selection for the teaching reform of non-computer majors in higher vocational education is put forward.
\end{abstract}

\section{Introduction}

With the continuous development of the information technology and the continuous progress of the society, the employers also have higher requirements for the talents. The computer course is not only set up for the students in the computer majors of higher vocational colleges, but also becomes more important for the students in the non-computer majors of higher vocational colleges. Therefore, the computer teaching of the non-computer majors in higher vocational colleges shall be reformed in order to train the skilled talents who can serve their specialties skillfully with the computer technology. Although China has included the computer basic course into the basic common required courses of higher vocational colleges for a long time, there still are many teaching difficulties that need to be solved.

\section{Obvious Problems in Computer Teaching of Non-computer Majors in Higher Vocational Colleges}

Firstly, the basic knowledge of the students in non-computer majors of the higher vocational college in computer learning is different greatly. In recent years, China has continued to expand the enrollment scale of the colleges and universities, resulting in the increasing number of the students in higher vocational colleges. Because of the differences in the regional culture and economic development level and the personal factors of the students, the structure of the students of higher vocational colleges is very completed, which is shown in the computer teaching of non-computer majors is that there are great differences among the students in the basic knowledge for learning computer. Some vocational college students are born in cities, who have more chances to contact with the computer in their daily life, so they will operate the computer smoothly; but there are some higher vocational college students come from the areas where the economic development is relatively lagging, who have relatively less chances to contact with the computer, so they will have a lot of difficulties in learning computer, thus bringing a prominent problem for the computer teaching in the non-computer majors of higher vocational colleges. 
Secondly, the computer textbooks for the non-computer majors in higher vocational colleges are updated too slowly. Nowadays, the modern information technology is developing quickly, which leads a more and more obvious problem that the content of the computer textbooks for the non-computer majors in higher vocational colleges deviates from the current era development. Under this historical background, the computer teachers in higher vocational colleges shall continue to create new teaching methods in order to improve the quality of the education and teaching in higher vocational colleges. However, the teachers of the computer courses in the higher vocational colleges in China are obviously not as strong as those in regular colleges and universities, which lead to the low computer teaching level in the higher vocational colleges and the lagging teaching methods, and the failure to realize the cultivation of the high skilled talents in higher vocational colleges. Meanwhile, because the overall teaching quality of the computer courses of non-computer majors in higher vocational colleges is not high, some students have to learn the new knowledge and new skills by self-study. However, according to the relevant survey, the effectiveness of such self-study is not remarkable. At present, there are some problems in the computer textbooks popular in the libraries of the higher vocational colleges and the market, which mainly is shown in the unreasonable content arrangement and disordered knowledge structure in some computer books. The above problems are very easy to hinder the students of the non-computer majors in higher vocational colleges from learning the computer. In view of this, the higher vocational colleges must continue to update the computer textbooks and arrange all teaching tasks scientifically in accordance with their own teaching characteristics.

Thirdly, the investment in the hardware and software facilities for the computer teaching in higher vocational colleges is insufficient. At present, there is still a big problem in the computer teaching of non-computer majors in higher vocational colleges, which is the scarce investment in the hardware and software facilities for education and teaching. This is mainly because the scale of the higher vocational colleges is small, their capital strength is fairly weak, and their attention to the computer courses is not enough, all of which make the students of the non-computer majors learn the high-quality computer course difficultly. The above problems will cause a considerable part of computer courses to be completed difficultly, and will greatly weaken the initiative of the students of the non-computer majors to learn computer. Therefore, the higher vocational colleges shall solve this problem by introducing some social resources and the support of national policies.

Fourthly, the teaching method is too monotonous, which leads to the failure to show the students' subjectivity. At present, a large number of higher vocational schools have fixed and stereotyped the computer teaching. In the computer teaching process, teachers only pay attention to the monotonous explanation, but ignore the practical operation, and only emphasize their own teaching and students' learning, but let students operate the computer by read the books entirely. For example, teachers conduct the practice guidance for students only by one time of computer operation process and they don't give students the opportunity to ask questions. The result is that the teachers are teaching in the whole class and students have no time to the carry out the practical operation. In this way, the new teaching concept with students as the main body is not reflected, there is no communication between the teachers and the students, and it is difficult to mobilize the learners' initiative in learning effectively. Although they will allocate a period of time for the computer teachers to practice, the students are difficult to consolidate the theoretical knowledge with the practical knowledge timely and unable to master all knowledge, so the teaching effectiveness is often not ideal.

\section{Countermeasure Selection for Teaching Reform of Non-computer Majors in Higher Vocational Colleges}

\subsection{Reform the teaching method for non-computer majors in higher vocational colleges actively}

To train the computer practical application ability of the students of the non-computer majors in higher vocational colleges, the modern information technology shall be mastered fairly, and the computer learning form of the students in the non-computer majors of traditional higher vocational 
colleges shall be reformed comprehensively. Especially the pure theoretical teaching method shall be avoided, which shall be combined with the practice to create the new diversified teaching forms. Moreover, the integration of teaching and learning, and learning and practice shall be insisted to constantly improve the ability of the vocational college students to ask questions, analyze the problems and solve the problems. The important role of the modern information technology teaching shall be played fully and the individualized teaching shall be promoted constantly. It is necessary to connect the education and teaching with the latest development trends of current computer industry, popularize the latest scientific and technological development achievements in the computer industry among the vocational college students so that they can know the new development direction of the new technology in the computer field, and continue to improve the establishment of the computer practice base, so as to provide a first-class computer learning environment for the vocational college students. On in this way, the enthusiasm of the vocational college students of non-computer majors in learning the computer technology can be further increased and the computer teaching quality in higher vocational colleges can be constantly improved. Next there are two new computer teaching methods for the non-computer majors in higher vocational colleges that are introduced.

The first is to implement the theory teaching objective by grouping cooperation. The main step is to divide the vocational college students into groups and each group contains four to six persons to solve problems on the computer together and implement the targeted operations. Therefore, this teaching method can not only stimulate the students' imagination and creativity, but also improve their teamwork consciousness, and then make them integrate into the computer learning unconsciously, thus mobilizing the enthusiasm of the vocational college students in learning computer and further improving the computer teaching effect. The computer teachers in higher vocational colleges can carry out the interactive teaching in the computer class and summarize the difficult knowledge points according to the different characteristics of the students. Moreover, they can strengthen the interaction in the classroom teaching based on demonstrating the concrete operation process of the computer. Teachers operate first and then students follow them. In this way, not only a more equal relationship between teachers and students can be formed, but also the students' computer practice ability can be improved. For example, while using Word2007, the computer teachers can show the campus propaganda materials or hand-made newspaper to the students in advance in accordance with the specific circumstance, and tell the students that they can realize the effect by wordart, pictures and optional figures, and then students can discuss the concrete solutions in groups and then submit the works to teachers after the actual operation. For the problems that students encounter in the group production, teachers can conduct feedback according to the actual situation and promote teaching step by step.

The second is to realize the operating practice by scene reappearance. The computer teachers of higher vocational colleges can apply the scene reappearance method in the computer teaching process comprehensively, which is mainly based on the specific problems encountered in the restoration of computer teaching, so that the vocational college students can communicate with the each other through operation and month and then solve the problems better. In this way, not only the students in non-computer majors of higher vocational colleges can master the computer knowledge in a relaxed and joyful environment, but also improve their enthusiasm in learning computer. In addition, this method can let the vocational college student learn all computer contents personally on the scene, so that they will have more enthusiasm in learning computer, develop a good habit of listening carefully under the unconscious influence, and master more computer knowledge in the practical operation, thereby speeding up the progress of classroom teaching. Meanwhile, the interaction between teachers and students and among students can be carried out. Teachers ask questions to students, and the students answer according to the previous operation. Therefore, by this teaching method, twice the result with half the effort can be got. 


\subsection{Improve the setting of computer courses of non-computer majors in higher vocational colleges}

In recent years, some higher vocational colleges only have focused on the grade examination of computer courses of non-computer majors, but ignored the teaching of computer technology, which leads to the situation that the vocational college students can master the computer knowledge skillfully but lack the application of related software. This course setting form not only affects the improvement of the skill level of the students of non-computer majors to a great extent, but also is inconsistent with the concept of running higher vocational colleges. Therefore, the higher vocational colleges shall set up the computer courses of non-computer majors according to characteristics of each major and combine the professional teaching with the computer teaching closely. For example, generally the machinery majors in higher vocational colleges need to set up some software courses, such as CAD and UG; the graphic design major usually needs to set up some software courses, such as PS and AI; accounting major needs to set up the practical software operation course. Only the courses set up by different majors meet the actual needs of different major practically, the practical operating skills of the students of non-computer majors can be improved better.

\subsection{Strengthen the talent construction of teachers for non-computer majors in higher vocational colleges}

In the process of promoting the construction of computer teachers for non-computer majors in higher vocational colleges, the following three points should be mainly carried out. First of all, strengthen the training of vocational ability for higher vocational teachers and implement the new idea of people-oriented teaching. In the concrete teaching process, the higher vocational teachers shall study with the students as guiders, and carry out the comprehensive guidance according to the questions asked by the students in practice, to show more guiding function of the higher vocational teachers to the students. Secondly, the higher vocational teachers shall continue improving their knowledge reserve ability and teaching ability and actively create new teaching theories. What's more, the computer teachers in higher vocational colleges shall grasp the teaching theory of computer major deeply and thoroughly, participate in various academic exchanges related to the computer teaching of higher vocational colleges initiatively, and improve the ability of teaching and research constantly. Thirdly, the higher vocational colleges shall actively introduce teacher employment system and continue strengthening the introduction of high-quality computer teachers. The higher vocational colleges must be committed to the innovation of the employment system of computer teachers, improve the management mode of computer teachers constantly to get an appropriate cooperative way, and strengthen the overall quality of computer education in higher vocational colleges continuously.

\subsection{Increase the investment in computer teaching of non-computer majors in higher vocational colleges}

The higher vocational colleges shall constantly increase the investment in the computer teaching of non-computer majors, weed out the lagging teaching facilities and equipment as far as possible, and purchase the most advanced education and teaching equipment to create a better teaching situation for the vocational college students. In order to match the vocational college students' vocational abilities with the actual job demands, the higher vocational colleges shall actively seek the cooperation with related enterprises, explore the promotion of directional training, use all kinds of enterprise resources, and constantly improve the combination of theoretical knowledge and practical skills of the students of non-computer majors and the utilization rate of education and teaching resources. 


\section{Conclusion}

To sum up, there are still a lot of problems in the computer course teaching of non-computer majors in higher vocational colleges at present, which require the computer teachers to closely contact with the students' practical conditions, and continue to explore and choose more scientific teaching means and methods, so as to lay a foundation for the future study and work of the vocational college students to meet the actual demands of the current employers better, and then cultivate more innovative, high-quality and skilled vocational talents.

\section{References}

[1] Niu Xiaomei, Grasp Students' Personal Characteristics Dynamically by Objective-based Teaching Method - Some Opinions on Teaching Reform of Basic Computer Courses in Colleges , Hunan Education (midmonth periodical), 2011 (4) .

[2] Yang Juan, Paul Liu, Hu Yong, Analysis and Exposition of Reform Mode of Basic Computer Teaching for Non-computer Majors , Journal of Higher Education, 2017 (9) .

[3] Niu Juntao, Analysis of Current Situation of Computer Teaching for Non-computer Majors in Higher Vocational Colleges, The Journal of Shandong Agricultural Engineering College, 2016 (8) .

[4] Zhang Lingling, Research on Demand for Computer Application Ability and Information Literacy of Students of Non-computer Majors in Higher Vocational Colleges, Heilongjiang Science and Technology Information, 2016 (35). 